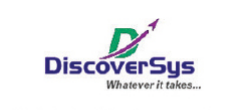

Published by DiscoverSys
${ }^{1}$ Faculty of Medicine and Health Sciences, Atma Jaya Catholic University of Indonesia 2Department of Ethics, Faculty of Medicine and Health Sciences, Atma Jaya Catholic University of Indonesia ${ }^{3}$ Department of Public Health and Nutrition, Faculty of Medicine and Health Sciences, Atma Jaya Catholic University of Indonesia ${ }^{4}$ Department of Obstetrics and Gynecology, Faculty of Medicine and Health Sciences, Atma Jaya Catholic University of Indonesia

*Correspondence to: Fegita Beatrix Pajala; Faculty of Medicine and Health Sciences, Atma Jaya Catholic University of Indonesia; fegita pajala@yahoo.com

\title{
The relationship between inter-pregnancy interval and gestational age with labor complications at the Sele Be Solu Regional Public Hospital of Sorong City, West Papua
}

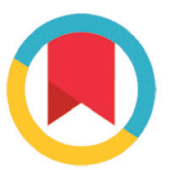

CrossMark

\author{
Fegita Beatrix Pajala ${ }^{1}$, Erfen Gustiawan Suwangto ${ }^{2}$, Yunisa Astiarani $^{3}$, Astrid Fransisca Padang ${ }^{4}$
}

\section{ABSTRACT}

Background and purpose: Labor complications are conditions during or after labor that can threaten life of the mother and the baby to be born. Some factors have been associated with labor complications, including inter-pregnancy interval and gestational age. This study was conducted to determine the relationship between inter-pregnancy interval and gestational age with labor complications at the Sele Be Solu Regional Public Hospital of Sorong City.

Methods: This study was an analytic observational study with a cross-sectional design. The samples of this study were pregnant women who gave birth at the Sele Be Solu Regional Public Hospital of Sorong City in 2016-2018 and met the inclusion criteria. We used secondary data from the medical records retrieved in July to August 2019. We retrieved mothers' identities (age, education, employment status), inter-pregnancy interval, gestational age and labor complications. A number of 261 samples (121 with labor complications and 140 without labor complications) were selected using convenience sampling technique. Descriptive analysis and Chi-Square test with SPSS 25.0 were performed.

Results: Most of the mothers (85.8\%) were in the non-high-risk

age group, graduated from senior high school or above (82\%), were not employed/housewives (68.6\%), the majority (67.8\%) of inter-pregnancy interval was in the non-high-risk group, more than half $(52.5 \%)$ of gestational age was in the high-risk group and the most common type of complications (17.2\%) was the premature rupture of membranes. There were significant relationship between age $(p<0.001 ; 0 R=5.201 ; 95 \%(\mathrm{l}$ : 2.275-11.889), inter-pregnancy interval $(\mathrm{p}<0.001 ; 0 \mathrm{R}=2.955 ; 95 \% \mathrm{Cl}: 1.722-5.070)$ and gestational age $(p<0.001 ; 0 R=4.606 ; 95 \% C l: 2.722-7.794)$ with labor complications. There were no relationship between education ( $p=0.166 ; 0 \mathrm{R}=0.599 ; 95 \% \mathrm{Cl}: 0.312-1.151)$ and employment status ( $p=0.230 ; 0 R=1.428 ; 95 \% \mathrm{Cl}: 0.845-2.412$ ) with labor complications.

Conclusions: There are significant relationship between inter-pregnancy interval and gestational age with labor complications. Health offices and health workers have an essential role in minimizing the risk of labor complications by providing early detection of possible labor complications and active counseling to the community especially women of childbearing age.

Keywords: labor complications, inter-pregnancy interval, gestational age

Cite this Article: Pajala, F.B., Suwangto, E.G., Astiarani, Y., Padang, A.F. 2020. The relationship between inter-pregnancy interval and gestational age with labor complications at the Sele Be Solu Regional Public Hospital of Sorong City, West Papua. Public Health and Preventive Medicine Archive 8(2): 162-167. D0I: 10.15562/phpma.v8i2.311

\section{INTRODUCTION}

The maternal mortality rate (MMR) is an indicator in assessing public health status of a country. The latest data from the ASEAN Statistical Reports on Millennium Development Goals 2017 showed that MMR in Indonesia is still categorized as high reported at 305 per 100,000 live births. ${ }^{1}$ The 2017 West Papua Health Profile data reported that Sorong City is the area in West Papua with the highest number of maternal mortality rates in 2017, which reached more than 5,000 maternal deaths. ${ }^{2}$

Some factors contribute to maternal mortality can be divided into direct causes, indirect causes and non-specific (unknown) causes. The direct causes occur as a result of complications during pregnancy, labor and the puerperium ${ }^{3,4}$ The indirect causes include pre-existing illnesses or illnesses that arise during pregnancy which consist of factors that worsen the pregnancy, such as being too young, too old, too frequent childbirths and inter-pregnancy interval (IPI) that is too close. ${ }^{4}$ Other factors beyond obstetrics and gynaecology that can increase the risk of maternal mortality are chronic and metabolic diseases. ${ }^{5}$

Labor complications defined as the conditions during and after childbirth that can threaten the life of the mother and baby. Labor complications can increase the risk of morbidity and mortality for both. IPI defined as the time between delivery of the previous infant and conception of the current pregnancy. ${ }^{6}$ IPI has an important role in family planning because it will not only affect the age difference between children, but it can affect both the mother and the baby. Previous studies have shown the association between the IPI and perinatal 
adverse outcomes such as small for gestational age, stillbirth, preterm delivery and neonatal death. ${ }^{7,8}$ However, not many studies have been conducted to identify the association between IPI and labor complications especially in setting such as Papua. ${ }^{8}$

Gestational age during labor defined as the length of the gestation period since the first day of the last menstrual period which is usually expressed in weeks and days. ${ }^{9}$ Several studies showed that there was a strong relationship between gestational age and labor complications. High risk gestational age (preterm (less than 37 weeks) or post-term (more than 42 weeks)) are associated with labor complications in the form of bleeding through the birth canal, prolonged labor, mothers experiencing seizures, turbid and smelly amniotic fluid, the mother cannot bear to push and the mother is experiencing anxiety or intense pain during labor. ${ }^{10-12}$

WHO reported around 830 women die every day due to pregnancy and labor complications. The risk of a woman in developing countries to die from maternal-related causes is 33 times higher than those living in developed countries. ${ }^{13}$ Complications during pregnancy and labor are the leading causes of mortality and disability in reproductive-age women in developing countries. ${ }^{14}$ The most commonly reported complications were anxiety or intense pain (53.5\%) and prolonged labor (40.6\%). ${ }^{15}$ Data from the Sele Be Solu Regional Public Hospital of Sorong City recorded that there were 246 mothers who gave birth with labor complications in 2016. ${ }^{16}$

There is limited evidence in explaining the relationship between IPI and gestational age with labor complications, especially in Sorong City. The purpose of this study was to determine the relationship between IPI and gestational age during labor with labor complications at the Sele Be Solu Regional Public Hospital of Sorong City.

\section{METHODS}

This study was an analytic observational study with a cross-sectional approach in which the data associated with the independent and the dependent variables were collected at the same time. The study was conducted on 261 mothers who gave birth at the Sele Be Solu Regional Public Hospital of Sorong City in the period of January 1, 2016 - December 31, 2018 who met the inclusion and exclusion criteria. The data used for this study were secondary data from medical records. The inclusion criteria in this study were pregnant women who gave birth at the Sele Be Solu Regional Public Hospital of Sorong City in 2016-2018 and had complete medical record data in the form of patient registration numbers, patient identities (age, education, employment status), IPI, gestational age during labor and labor complications. The exclusion criteria in this study were mothers with multiple gestations, mothers with first pregnancies, mothers with absolute narrow hips and mothers with blood clotting disorders.

The independent variables were IPI and gestational age during labor and delivery. IPI defined as the time between delivery of the previous infant and conception of the current pregnancy. Gestational age during labor was the length of the gestation period since the first day of the last menstrual period which is usually expressed in weeks and days. The dependent variable was labor complications. Labor complications defined as the conditions during and after childbirth (stage I-IV) that can threaten the life of the mother and the baby. Other variables (confounding) collected and analyzed were mothers' age, education and employment status. Age defined as the length of time a person lives. Education defined as the last educational institution completed by a person. Employment status defined as something that is done for a living, or a livelihood.

The convenience sampling technique was used to select the sample. Convenience sampling is a sampling technique where subjects meet the inclusion criteria and are easily accessible for the researcher. A minimum sample of 96 subjects were calculated using the cross-sectional formula with $95 \%$ level of confidence, $80 \%$ power, $10 \%$ precision and because the proportion of labor complications in population was unknown, we assumed the proportion by $50 \%$. After we collected the data from medical records, each variable were categorized based on certain ranges. There were two groups for each variables, for mothers age the data categorized as non-high risk (20-35 years) and high-risk $(<20$ or $>35$ years), for mothers education the data categorized as junior high school/below and senior high school/above, for mother employment status the data categorized as unemployed and employed, for IPI the data categorized as non-high risk (2-5 years) and high risk ( $<2$ or $>5$ years $)$ and for gestational age the data categorized as non-high risk (37-42 weeks) and high risk ( $<37$ or $>42$ weeks).

Univariate analysis was carried out by describing each of the variables. The data was displayed in the form of a frequency distribution table. Bivariate analysis was performed to determine the relationship between variables. SPSS Statistics 25.0 for Windows was used to analyse the univariate and bivariate variables. Chi-square Test was conducted to determine the relationship between inter pregnancy interval and gestational age with labor complication.

The study was performed by main researcher and 
Table 1. Socio-demographic characteristics, inter-pregnancy interval and gestational age of mothers who give birth at Sele Be Solu Hospital

\begin{tabular}{|c|c|c|}
\hline Characteristics & $\mathbf{n}$ & $\%$ \\
\hline \multicolumn{3}{|l|}{ Age } \\
\hline Non high risk ${ }^{\star}$ & 224 & 85.8 \\
\hline High risk ${ }^{* *}$ & 37 & 14.2 \\
\hline \multicolumn{3}{|l|}{ Education } \\
\hline$\leq$ Junior High & 47 & 18.0 \\
\hline$\geq$ Senior High & 214 & 82.0 \\
\hline \multicolumn{3}{|l|}{ Employment } \\
\hline Unemployed & 179 & 68.6 \\
\hline Employed & 82 & 31.4 \\
\hline \multicolumn{3}{|c|}{ Inter-Pregnancy Interval } \\
\hline$<2$ years & 40 & 15.3 \\
\hline $2-5$ years & 177 & 67.8 \\
\hline$>5$ years & 44 & 16.9 \\
\hline \multicolumn{3}{|l|}{ Gestational Age } \\
\hline Non high risk ${ }^{*}$ & 124 & 47.5 \\
\hline High risk ${ }^{* *}$ & 137 & 52.5 \\
\hline Total & 261 & 100 \\
\hline${ }^{*}$ Non high risk age: $20-35$ & & $:<20$ or $>35$ years \\
\hline${ }^{*}$ Non high risk gestational & eks & $\begin{array}{l}\text { tational age: } \\
\text { weeks }\end{array}$ \\
\hline
\end{tabular}

a trained research assistant. This study was approved by the Ethics Committee of Faculty of Medicine and Health Sciences, Atma Jaya Catholic University of Indonesia (No: 17/07/KEP-FKUAJ/2019) on July $1^{\text {st }}, 2019$.

\section{RESULTS}

The results of this study showed that most of the mothers $(85.8 \%)$ were in the non-high-risk age group (20-35 years), graduated from senior high school or above $(82 \%)$, were not employed/ housewives $(68.6 \%)$. The majority $(67.8 \%)$ of IPI was in the non-high-risk group (2-5 years), more than half $(52.5 \%)$ gestational age was in the highrisk group ( $<37$ or $>42$ weeks) (Table 1$)$. The most prevalent type of complications at $17.2 \%$ was the premature rupture of membranes (Table 2).

The results of the bivariate analysis with a confidence interval (CI) of $95 \%$ showed that there was a significant relationship between maternal age $(\mathrm{OR}=5.201 ; 95 \% \mathrm{CI}: 2.275-11.889 ; \mathrm{p}<0.001)$ with labor complications but there were no relationship between maternal education $(\mathrm{OR}=0.599$; 95\%CI:
$0.312-1.151 ; \mathrm{p}=0.166)$ and employment status $(\mathrm{OR}=1.428 ; 95 \% \mathrm{CI}: 0.845-2.412 ; \mathrm{p}=0.230)$ with labor complications (Table 3 ).

The results of the bivariate analysis with CI of $95 \%$ showed that there were a significant relationship between IPI (OR=2.955; 95\%CI: 1.722-5.070; $\mathrm{p}<0.001)$ and gestational age $(\mathrm{OR}=4.606 ; 95 \% \mathrm{CI}$ : 2.722-7.794; $\mathrm{p}<0.001)$ with labor complications (Table 4).

\section{DISCUSSION}

We found that most of the mothers (85.8\%) were in the non-high-risk age group, graduated from senior high school/above (82\%), not employed/ housewives $(68.6 \%)$, the majority $(67.8 \%)$ of IPI was in the non-high-risk group, more than half $(52.5 \%)$ of gestational age was in the high-risk group and the most common type of complications $(17.2 \%)$ was the premature rupture of membranes. These results are consistent with several previous studies. ${ }^{17-19}$

This research showed that there was a relationship between maternal age and labor complications. Mothers with high-risk age have greater risk of experiencing labor complications. ${ }^{17,20}$ This can be caused by several factors such as psychological conditions, the maturity of reproductive organs, and conditions of the pelvis and uterus in mothers aged $<20$ years that are not fully mature to support pregnancy and delivery. Mothers aged $>35$ years are at risk of experiencing labor complications related to decreased ability to push during delivery, particularly in mothers with chronic and degenerative diseases involving the pelvis and spinal joints. ${ }^{17,21}$

According to this study, there was no relationship between education level and labor complications. This is consistent with the results of a study conducted by Simarmata et al. (2015), ${ }^{22}$ but it opposes the results of Moreira et al study (2017). ${ }^{23}$ The theory stating that pregnant women with higher levels of education tend to absorb new information more easily so that it may associate with better understanding on monitoring the progress of their pregnancy. ${ }^{18,23}$ These differences can be caused by different times and locations of study as well as differences in data collection and potentially population selection bias.

We found that there was no relationship between maternal employment status and labor complications. The results of this study are inconsistent with the research by Khojasteh et al. (2015) which reported a relationship between physical work and decreased amniotic fluid (oligohydramnios). ${ }^{19}$ One of the limitations in this research was that the type of employment of 
Table 2. Distribution of labor complications

\begin{tabular}{|c|c|c|}
\hline Characteristics & $\mathbf{n}$ & $\%$ \\
\hline \multicolumn{3}{|l|}{ Labor Complications } \\
\hline $\begin{array}{l}\text { Premature rupture of } \\
\text { membranes }\end{array}$ & 45 & 17.2 \\
\hline Prolonged labor & 19 & 7.3 \\
\hline Perineal tears & 15 & 5.7 \\
\hline Placental retention & 13 & 5.0 \\
\hline Nuchal cord & 10 & 3.8 \\
\hline Uterine inertia & 8 & 3.1 \\
\hline Postpartum hemorrhage & 5 & 1.9 \\
\hline Antepartum hemorrhage & 3 & 1.1 \\
\hline Uterine atony & 2 & 0.8 \\
\hline Umbilical cord prolapse & 1 & 0.4 \\
\hline Total & 121 & 100 \\
\hline
\end{tabular}

Table 3. The relationship between maternal socio-demographic characteristics with labor complications

\begin{tabular}{|c|c|c|c|c|c|}
\hline \multirow{3}{*}{ Variables } & \multicolumn{4}{|c|}{ Labor Complication } & \multirow{3}{*}{$\begin{array}{c}\text { 95\%Cl } \\
\text { Lower-Upper }\end{array}$} \\
\hline & Without & With & $\mathbf{p}$ & OR & \\
\hline & $\begin{array}{c}\text { Complication } \\
\text { n (\%) }\end{array}$ & \multicolumn{2}{|l|}{$\begin{array}{c}\text { Complications } \\
\text { n (\%) }\end{array}$} & & \\
\hline \multicolumn{6}{|l|}{ Age } \\
\hline Non high risk ${ }^{*}$ & * $132(58.9)$ & $92(41.1)$ & & & \\
\hline High risk ${ }^{\star *}$ & $8(21.6)$ & $29(78.4)$ & $<0.001$ & 5.201 & $2.275-11.889$ \\
\hline \multicolumn{6}{|l|}{ Education } \\
\hline$\leq$ Junior high & $110(51.4)$ & $104(48.6)$ & & & \\
\hline$\geq$ Senior high & $30(63.8)$ & $17(36.2)$ & 0.166 & 0.599 & $0.312-1.151$ \\
\hline \multicolumn{6}{|l|}{ Employment } \\
\hline Unemployed & $101(56.4)$ & $78(43.6)$ & & & \\
\hline Employed & $39(47.6)$ & $43(52.4)$ & 0.230 & 1.428 & $0.845-2.412$ \\
\hline
\end{tabular}

${ }^{*}$ Non high risk: $20-35$ years ${ }^{* *}$ High risk $:<20$ or $>35$ years

the mothers studied was insufficient because data collection was carried out through medical records, then the physical workload (work duration, length of standing/sitting/bending, and other aspects related to the mothers' occupations) were not researched specifically.

This study showed that there was a relationship between IPI and labor complications. Mothers with a high-risk IPI had a 3 times higher risk of experiencing labor complications. This results are consistent with previous studies. ${ }^{24,25}$ Sanga et al. (2020) reported that a long IPI (>5 years) increased the risk of labor complications in the form of postpartum hemorrhage. ${ }^{26}$ The short IPI is associated with maternal depletion syndrome, which is when the mother does not have sufficient time between the previous and subsequent pregnancies to restore the supply of macronutrients and micronutrients, so this condition can have a negative impact to the mother and the fetus. Besides, the increased risk of labor complications at a risky IPI can be caused by stress, considering that caring for and breastfeeding the child after the subsequent pregnancy can be both a physical and emotional burden for the mother. Another factor that influences is inadequate time for hormonal recovery and healing of genital organs injured after previous pregnancy and labor. ${ }^{27}$ Although there is a decrease in the risk of labor complications with increasing IPI, the long IPI is also associated with labor complications. ${ }^{28}$ This is due to the increase in IPI is directly proportional to the mother's age. The longer the IPI, the older the mother, so that the risk of labor complications increases.

This study showed a relationship between gestational age and labor complications. Mothers with a high-risk gestational age had a 4.6 times higher risk of experiencing labor complications. Previous studies reported that preterm labor was associated with labor complications in the form of antepartum bleeding, poly/oligohydramnios and vaginal/urinary infections. ${ }^{29,30}$ The exact cause of preterm labor is currently under research. Based on the existing theory, preterm labor can be caused by the termination of pregnancy, premature rupture of membranes in premature pregnancy, multiple pregnancy and idiopathic. In this study, there was only one sample with a gestational age of more than 42 weeks (post-term) who had labor complications. This may because in some cases, women with obstetric complications are more likely to experience induction of labor before 42 weeks of gestation, so the potential for post-term pregnancy can be reduced. ${ }^{31}$

If mothers can manage IPI according to WHO recommendations (at least 18 months from the birth of the last child) and increase their knowledge of factors that can contribute to labor complications, the incidence of labor complications can be minimized. It also requires cooperation from various parties, including the government, health workers and other stakeholders to reduce the incidence of labor complications through various regulations, policies and efforts to improve the welfare of the mother and the baby. Several measures that can be done are through early detection of mothers with risk factors and active counseling to the community especially to women of childbearing age.

This study has several limitations, it does not collect detailed data regarding mother employment status (physical workload) because data collection was carried out through secondary data (medical 
Table 4. The relationship between inter-pregnancy interval and gestational age with labor complications

\begin{tabular}{|c|c|c|c|c|c|}
\hline \multirow[b]{2}{*}{ Variables } & \multicolumn{5}{|c|}{ Labor Complication } \\
\hline & Without & With & $\mathbf{p}$ & OR & $95 \% \mathrm{Cl}$ \\
\hline & $\begin{array}{c}\text { Complication } \\
n(\%)\end{array}$ & $\begin{array}{c}\text { Complications } \\
n(\%)\end{array}$ & & & Low - High \\
\hline
\end{tabular}

Inter-Pregnancy

Interval (years)

$\begin{array}{llllll}\text { Non high risk * } & 110(62.1) & 60(37.9) & & & \\ \text { High risk * }^{*} & 30(35.7) & 54(64.3) & <0.001 & 2.955 & 1.722-5.070\end{array}$

Gestational Age

(weeks)

\begin{tabular}{lllllll} 
Non high risk * & $90(72.6)$ & $34(27.4)$ & & & \\
High risk $^{*}$ & $50(36.5)$ & $87(63.5)$ & $<0.001$ & 4.606 & $2.722-7.794$ \\
\hline
\end{tabular}

${ }^{*}$ Non high risk IPI: $2-5$ years

* Non high risk gestational age: $37-42$ weeks

${ }^{\star *}$ High risk IPI: $<2$ or $>5$ years

${ }^{\star *}$ High risk gestational age :

$<37$ or $>42$ weeks

records), therefore further research regarding the length of physical activity of the mothers during pregnancy is needed. In addition, the study was conducted only among patients in one hospital, so its generalization may be limited to those settings with similar characteristics.

\section{CONCLUSION}

This study reports significant relationship between IPI and gestational age with labor complications. Mothers with high-risk IPI had a three times higher risk of experiencing labor complications, while mothers with high-risk gestational age had a 4.6 times higher risk of experiencing labor complications.

Prevention and early detection of labor complications play an important role in reducing the adverse outcome of labor and delivery. We recommend health offices and health workers to improve the labor outcome by providing early detection of possible labor complications and active counseling to the community especially to women of childbearing age.

\section{Acknowledgement}

The authors would like to thank the Director of Sele Be Solu Regional Public Hospital of Sorong City, West Papua and staff who have given permission and support the data collection of this study.

\section{Author contribution}

FBP, EGS, YA and AFP designed the study. FBP collected and analysed the data, wrote the first draft of manuscript and edited the manuscript. EGS and YA provided feedback and input to the manuscript and data analysis. EGS, YA and AFP reviewed the study proposal and manuscript critically.

\section{Conflict of interest}

No conflicts of interest declared by the authors.

\section{Funding}

The study was self-funded by the authors.

\section{REFERENCES}

1. The Association of Southeast Asian Nations Secretariat. Association of Southeast Asian Nations Statistical Report on Millennium Development Goals 2017. Jakarta: ASEAN Secretariat 2017. p. 38.

2. West Papua Provincial Health Office. Profil Kesehatan Provinsi Papua Barat tahun 2017 [2017 West Papua Province Health Profile]. Manokwari: West Papua Provincial Health Office.2018. p. 32.

3. World Health Organization. Trends in Maternal Mortality: 1990 to 2015. World Health Organizations; 2015.

4. Kusuma J, Saifuddin AB, Abdulmuthalib. Ilmu Kebidanan [Midwifery Science]. 4th ed. Jakarta: PT Bina Pustaka Sarwono Prawirohardjo. 2014. p. 53-55.

5. Stokes M, Wilkinson J. The causes of maternal mortality are changing and preventable. BJOG.2018;125:1262.

6. Shachar BZ, Lyell DJ. Interpregnancy interval and obstetrical complications. Obstet Gynecol Surv. 2012;67(9):584596.

7. Mahande MJ, Obure J. Effect of interpregnancy interval on adverse pregnancy outcomes in Northern Tanzania: A registry-based retrospective cohort study. BMC Pregnancy Childbirth. 2016;16(140).

8. Gebremedhin AT, Regan AK, Malacova E, Marinovich ML, Ball S, Foo D, et al. Effects of interpregnancy interval on pregnancy complications: protocol for systematic review and meta-analysis. BMJ Open. 2018;8(8).

9. Ranjana, Sinha A. Incidence, causes and feto-maternal outcomes of obstructed labour in a tertiary health care centre. Int J Reprod Contracept Obstet Gynecol. 2017;6(7):2817-21.

10. Khoshnood Shariati M, Karimi Z, Rezaienejad M, et al. Perinatal complications associated with preterm deliveries at 24 to 33 weeks and 6 days gestation (2011- 2012): A hospital-based retrospective study. Iran J Reprod Med. 2015;13(11):697-702.

11. Reddy UM, Rice MM, Grobman WA, et al. Serious maternal complications after early preterm delivery (24-33 weeks' gestation). Am J Obstet Gynecol. 2015;213(4):538.

12. Chaudhari SN, Bhikane DB. A clinical study of postdated pregnancy. Int J Reprod Contracept Obstet Gynecol. 2017;6:2077-82.

13. World Health Organization. Maternal mortality ratio (per 100,000 live births). [Internet]. World Health Organization. 2014 [cited 2019 May 2]. Available from: https://www. who.int/healthinfo/statistics/indmaternalmortality/en/.

14. World Health Organization. Maternal mortality. [Internet]. World Health Organization. 2018 [cited 2019 May 2]. Available from: https://www.who.int/gho/publications/ world_health_statistics/2018/EN_WHS2018_TOC.pd$\mathrm{f}$ ?ua $=1$.

15. Ministry of Health of The Republic of Indonesia. Survei Demografi dan Kesehatan Indonesia (SDKI) tahun 2017 [Indonesian Demographic and Health Survey (IDHS) 2017]. Jakarta: 2018.

16. Bame MD. Survei Kesehatan Kota Sorong 2016 [2016 Sorong City Health Survey]. Sorong; 2017.

17. Hariyani F, Murti NN, Wijayanti E. Hubungan usia, paritas, dan kelas ibu hamil dengan komplikasi persalinan di RSKB 
Sayang Ibu Balikpapan [Relationship between age, parity, and class of pregnant women with delivery complications at RSKB Sayang Ibu Balikpapan ] [Internet]. Mahakam Midwifery Journal. 2019 [cited 2020 April 20]. Available from: http://ejournalbidan.poltekkes-kaltim.ac.id/ojs/index.php/ midwifery/ article/view/116/70.

18. Hidayah P, Wahyuningsih HP, Kusmiatun. Hubungan tingkat risiko kehamilan dengan kejadian komplikasi persalinan di RSUD Panembahan Senopati Bantul [The relationship between the level of risk of pregnancy and the incidence of delivery complications in RSUD Panembahan Senopati Bantul]. J Kesehat Vokasional. 2018;3.

19. Khojasteh F, Arbabisarjou A, Boryri T, et al. The relationship between maternal employment status and pregnancy outcomes. Glob J Health Sci. 2015;8.

20. Cavazos-Rehg PA, Krauss MJ, Spitznagel EL, Bommarito $\mathrm{K}$, Madden T, Olsen MA, et al. Maternal age and risk of labor and delivery complications. Maternal Child Health J. 2014;19(6):1202-11.

21. Komariah S, Nugroho H. Hubungan pengetahuan, usia dan paritas dengan kejadian komplikasi kehamilan pada ibu hamil trimester III di Rumah Sakit Ibu dan Anak Aisyiyah Samarinda [The association between knowledge, age and parity with pregnancy complications among the third trimester pregnant mothers at RSIA Aisyiyah Samarinda]. J Kesehat Masy. 2020;5(2):83.

22. Simarmata OS, Sudikno S, Kristina K, Bisara D. Determinan kejadian komplikasi persalinan di Indonesia: Analisis data sekunder Riset Kesehatan Dasar 2010 [Determinants of delivery complications in Indonesia: Secondary data analysis of 2010 Basic Health Research]. J Kesehat Reprod. 2015;5(3):165-174

23. Moreira DDS, Gubert MB. Healthcare and sociodemographic conditions related to severe maternal morbidity in a state representative population, federal district, Brazil: A Cross-Sectional Study. PLos One. 2017;12(8).
24. Cofer FG, Fridman M, Lawton E, Korst LM, Nicholas L, Gregory KD. Interpregnancy interval and childbirth outcomes in California, 2007-2009. Matern Child Health J. 2016;20(S1):43-51.

25. Appareddy S, Pryor J, Bailey B. Inter-pregnancy interval and adverse outcomes: Evidence for an additional risk in health disparate populations. J Matern Fetal Neonatal Med. 2016;30(21):2640-2644.

26. Sanga LA, Mtuy T, Philemon RN, Mahande MJ. Inter-pregnancy interval and associated adverse maternal outcomes among women who delivered at Kilimanjaro Christian Medical Centre in Tanzania, 2000-2015. PLos One. 2020;15(2).

27. Kabano IH, Broekhuis A, Hooimeijer P. Inter-pregnancy intervals and maternal morbidity: new evidence from Rwanda. Afr J Reprod Health. 2015;19:77-86.

28. Gbremedhin AT, Regan AK, Malacova E, Marinovich ML, Ball S, Foo D, et al. Effects of interpregnancy interval on pregnancy complications: protocol for systematic review and meta-analysis. BMJ Open. 2018;8(8).

29. Granese R, Gitto E, D’Angelo G, et al. Preterm birth: seven-year retrospective study in a single centre population. Ital J Pediatr. 2019;45(1).

30. Fernandes $\mathrm{S}$, Chandra S. A study of risk factors for preterm labour. Int J Reprod Contracept Obstet Gynecol. 2015;130612.

31. Deng K, Huang Y, Wang Y, Zhu J, Mu Y, Li X, et al. Prevalence of postterm births and associated maternal risk factors in China: Data from over 6 million births at health facilities between 2012 and 2016. Sci Rep. 2019;9(1).

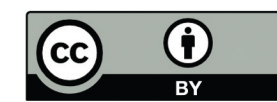

This work is licensed under a Creative Commons Attribution 